\title{
The effect of fiber post location on fracture resistance of endodontically treated maxillary premolars
}

\section{Wpływ umiejscowienia wkładu z włókna szklanego na odporność na złamanie zębów przedtrzonowych szczęki, leczonych endodontycznie}

\author{
Eshamsul Sulaiman ${ }^{1, A, E, F}$, Nada Alarami ${ }^{1, A-D, F}$, Yuh Ing Wong ${ }^{2, A-D}$, Wen Hui Lee ${ }^{2, A-D}$, Afaf Al-Haddad ${ }^{3, C, E, F}$ \\ 1 Department of Restorative Dentistry, Faculty of Dentistry, University of Malaya, Kuala Lumpur, Malaysia \\ ${ }^{2}$ Taiping Health Clinic, Malaysia \\ ${ }^{3}$ Department of Dental Materials and Equipment, Faculty of Dentistry, Mahsa University, Selangor, Malaysia \\ A - research concept and design; $B$ - collection and/or assembly of data; $C$ - data analysis and interpretation; \\ $D$ - writing the article; $E$ - critical revision of the article; $F$ - final approval of the article
}

Address for correspondence

Nada Alarami

E-mail: nada_alarmi@yahoo.com

\section{Funding sources}

Research grant No. ER002- 2011A, University of Malaya,

Kuala Lumpur, Malaysia.

Conflict of interest

None declared

Received on July 2, 2018

Reviewed on August 13, 2018

Accepted on August 27, 2018

DOI

10.17219/dmp/94656

Copyright

○ 2018 by Wroclaw Medical University

and Polish Dental Society

This is an article distributed under the terms of the

Creative Commons Attribution Non-Commercial License

(http://creativecommons.org/licenses/by-nc-nd/4.0/)

\begin{abstract}
Background. There is no sufficient literature on the effect of post location on endodontically treated premolar teeth with 2 roots.

Objectives. The aim of the study was to evaluate the effect of fiber post location on fracture resistance and failure mode of endodontically treated premolars with 2 roots.

Material and methods. Fifty extracted maxillary first premolars with 2 roots were divided randomly into 5 groups. Group 1 was comprised of sound teeth, which received only metal crowns (control). Teeth from groups 2, 3, 4, and 5 were decoronated $2 \mathrm{~mm}$ above the cementoenamel junction (CEJ) and were endodontically treated. No post was placed in group 2 teeth. Teeth from groups 3,4 and 5 were given a fiber post placed in the buccal canal, palatal canal, and both buccal and palatal canals, respectively. All teeth in groups 2, 3, 4, and 5 were built up with composite and full coverage metal crowns. A compressive static load was applied at an angle of $25^{\circ}$ to the crowns with a crosshead speed of $0.5 \mathrm{~mm} / \mathrm{min}$, until fracture.

Results. One-way analysis of variance (ANOVA) showed significant differences among the groups $(p=0.002)$. A post hoc test showed significantly lower fracture resistance of group 4 compared to group 5 ( $p=0.011$ ). Furthermore, group 2 had significantly less fracture resistance compared to group 1 $(p=0.021)$ and group $5(p=0.002)$. According to Fisher's exact test, different post locations are non-significantly associated with fracture mode $(p=0.256)$.

Conclusions. Fiber post location has a significant effect on fracture resistance of severely damaged, endodontically treated maxillary premolars with 2 roots. However, post placement in the palatal root is preferred, as it maintains the restorability of the tooth.
\end{abstract}

Key words: fracture mode, fracture resistance, fiber post, maxillary premolars with 2 roots, post location Słowa kluczowe: rodzaj złamania, odpornośćna złamanie, wkład z włókna szklanego, zęby przedtrzonowe szczęki z 2 korzeniami, umiejscowienie wkładu 


\section{Introduction}

Endodontically treated teeth are generally weaker and more prone to fracture compared to teeth that have not been root-filled, mainly due to loss of tooth structure from caries, trauma, or previous restorations, and access to the root canal itself. ${ }^{1}$ Loss of tooth structure due to access preparation results in increased cuspal deflection during mastication, which subsequently increases the possibility of cusp fracture and microleakage at the margin of the restorations. ${ }^{2}$ It has been suggested that fracture resistance of endodontically treated teeth is directly related to the remaining tooth structure, especially in the buccolingual dimension. ${ }^{3}$

Endodontically treated teeth can have a good prognosis and be restored to full function, even serving as an abutment for a fixed and removable prosthesis, when adequate root filling quality is ensured and sufficient tooth structure remains to support the final restoration. ${ }^{4,5}$ A post is recommended when the remaining coronal tooth structure is insufficient to retain a core build-up to support the final restoration. ${ }^{6-8}$ Different prefabricated post systems have been introduced and successfully used in clinical situations, which decreases chairside time and reduces the cost on the side of the patient. ${ }^{9}$ The glass fiber post is a well-accepted treatment modality for the restoration of endodontically treated teeth due to its superior mechanical properties, such as uniform stress distribution, higher fracture resistance, superior optical properties, and a modulus of elasticity similar to that of dentine. ${ }^{10,11}$

Posts are able to protect teeth from fracture by dissipating or distributing forces along the tooth. ${ }^{12}$ Posts are also indicated to increase the retention of the amalgam and composite core. However, not all endodontically treated teeth require a post, ${ }^{2}$ and since posts do not reinforce such teeth, ${ }^{13}$ their use should be limited to those with inadequate tooth structure. In addition, preparing space for the post is associated with some risk. ${ }^{2}$ Although rare, the risk includes perforation in the apical portion of the root or into the lateral fluted areas of the mid-root, called "strip perforation". ${ }^{14}$ The most common types of fractures in post-retained restorations are root fracture, loosening of the post and fracture of the post. ${ }^{15}$ Root fractures are most often unrestorable, which subsequently results in the extraction of the tooth. ${ }^{15}$

According to Gutmann, maxillary premolars often have marked tapering and thin roots, which increase the risk of root perforation and fracture. ${ }^{16}$ Additionally, furcation grooves or developmental depressions on the palatal side of the buccal root also increase the risk of endodontic and prosthodontic treatment fractures, because the average dentine layer at the deepest part of invagination was found to be too thin, equal to $0.81 \mathrm{~mm} .{ }^{17}$ In a retrospective study of 468 teeth that had fractured in vivo, $78 \%$ were premolars, with $62 \%$ of these being maxillary premolars. ${ }^{18}$
Since maxillary first premolars normally have 2 roots, dentists may face a dilemma while choosing the canal to place the post in (buccal or palatal, or both buccal and palatal). If possible, both canals of teeth with 2 roots should be utilized for post placement, since roots of premolars require bulk and length for the successful use of the post and core. ${ }^{19}$ To our knowledge, there has been no study on the effect of post location on endodontically treated premolar teeth with 2 separate roots. Thus, this study was conducted to compare the effect of fiber post location on fracture resistance and failure mode of endodontically treated maxillary first premolars with 2 roots.

\section{Material and methods}

Fifty non-carious, maxillary first premolars with 2 roots, extracted for periodontal reasons, were collected. All the teeth were disinfected in $0.5 \%$ chloramine-T solution for 1 week according to ISO/TS 11405 (2003). The selected premolars were examined under a stereomicroscope at $\times 10$ magnification (SZX7; Olympus Corporation, Tokyo, Japan) to ensure fracture-free roots. All external debris was removed from the roots with an ultrasonic scaler (Peizon ${ }^{\circledR}$ Master 400; Electro Medical Systems, Nyon, Switzerland). Tooth dimensions were measured using a digital caliper (Mitutoyo, Tokyo, Japan); teeth with a length of $21.5 \pm 1 \mathrm{~mm}$, root length of $14 \pm 1 \mathrm{~mm}$, buccolingual width of $8 \pm 1 \mathrm{~mm}$, and mesiodistal width of $6 \pm 1 \mathrm{~mm}$ were selected. The teeth were randomly and equally divided into 5 groups to be restored as follows:

- group 1 - no post/core, only metal crown restorations (control);

- group 2 - root canal treatment, composite core, metal crown (control);

- group 3 - fiber post placed in the buccal canal, followed by composite resin core and metal crown;

- group 4 - fiber post placed in the palatal canal, followed by composite resin core and metal crown;

- group 5 - fiber post placed in both the buccal and palatal canals, followed by composite resin core and metal crown.

All teeth except for group 1 were decoronated $17 \mathrm{~mm}$ from the apical end of the root toward the crown by means of a horizontal cut, perpendicular to the long axis of the root. Teeth in groups $2,3,4$, and 5 were endodontically treated. An access cavity was established in a conventional manner by using an endodontic access bur (Dentsply Maillefer, Ballaigues, Switzerland). Specimens were prepared using the step-back technique with K-files (Dentsply Maillefer). The working length was $1 \mathrm{~mm}$ shorter than the file length $(16 \mathrm{~mm})$. The master apical file used was size 30. The canals were repeatedly irrigated after each filing with $3.0 \mathrm{~mL}$ of $1 \%$ sodium hypochlorite solution $(\mathrm{NaOCl})$ (Clorox (Malaysia) Industries Sdn. Bhd., Kuala Lumpur, Malaysia). The teeth were obturated with gutta-percha cones (Dentsply Maillefer), using the lateral condensation technique and AH Plus ${ }^{\circledR}$ root canal sealer (Dentsply Maillefer). 
After the sealer had set, gutta-percha in groups 3, 4 and 5 was first removed by a heated endodontic plugger until canal orifices were seen. FRC Postec Plus ${ }^{\circledR}$ fiber posts (Ivoclar Vivadent, Schaan, Liechtenstein) size 0 with a diameter of $0.6 \mathrm{~mm}$ were used. The post space was prepared with a low-speed matching drill, which corresponded to the FRC Postec Plus fiber post size. Finally, $4 \mathrm{~mm}$ of guttapercha was left at the apex of the canals, where the post was indicated.

A thin layer of light-body, silicone-based impression material (Aquasil Ultra ${ }^{\circledR}$ XLV; Dentsply Maillefer) was first applied around the root surface to simulate the periodontal ligament. Each tooth was then embedded in coldcure epoxy resin $\left(\right.$ Mirapox $^{\circledR}-230 \mathrm{~A}$ and B; Miracon Sdn. Bhd., Kuala Lumpur, Malaysia), using a silicone mold $2 \mathrm{~mm}$ below the cementoenamel junction (CEJ), $4 \mathrm{~mm}$ from the coronal surface, to simulate the bone level.

The post length was standardized at $15 \mathrm{~mm}$. After trial insertion, the post was rinsed with normal saline, and then dried. First, adhesive (AdheSE ${ }^{\circledR}$ DC; Ivoclar Vivadent) was applied in the prepared canal and the coronal part of the tooth. Then, the post was cemented with MultiCore $^{\circledR}$ Flow dual-curing composite (Ivoclar Vivadent) according to the manufacturer's instructions. A matrix band was placed around the tooth to ease the core buildup procedure. The composite resin was flooded into the matrix to form the core until the desired height of $6 \mathrm{~mm}$ from the CEJ level was reached, covering the coronal end of the post. The occlusal surface was light-cured for $40 \mathrm{~s}$. The matrix band was then removed and an additional 40 $\mathrm{s}$ of polymerization was subsequently performed on the surfaces around the core to ensure complete setting of the core material.

Each specimen was prepared to receive a metal crown (Wiron ${ }^{\circledR}$ 99; Bego, Bremen, Germany). In order to standardize the preparation convergence angle, a diamond bur (998FG021 round-ended, tapered with a guide pin; NTI-Kahla GmbH, Kahla, Germany) was attached to a high-speed rotary handpiece, which was fixed to a paralleling device (custom-made at the Department of Mechanical Engineering, Faculty of Engineering, University of Malaya). A guide pin at the tip of the bur produced a standardized depth of the chamfer margin of $1 \mathrm{~mm}$. The core height of $6 \mathrm{~mm}$ from CEJ was marked by using a digital caliper (Mitutoyo). Occlusal reduction was done using a high-speed diamond bur (S811-314-037-7-ML; Swisstec 3D Akus AG, Uster, Switzerland) up to the marking line. A one-step impression technique was used to take the impression of the preparation specimens, using Impregum Soft Polyether Impression Material (Impregnum ${ }^{\circledR}$ Penta Soft ESPE; 3M, Maplewood, USA). The crowns were fabricated using a non-precious alloy. The axial and occlusal thicknesses of the crowns were standardized to $1 \mathrm{~mm}$ and $2 \mathrm{~mm}$, respectively, using a crown caliper and tungsten carbide burs. A small indentation, measuring $3 \mathrm{~mm}$ in diameter and $1 \mathrm{~mm}$ in depth, was made on the buccal cusp,

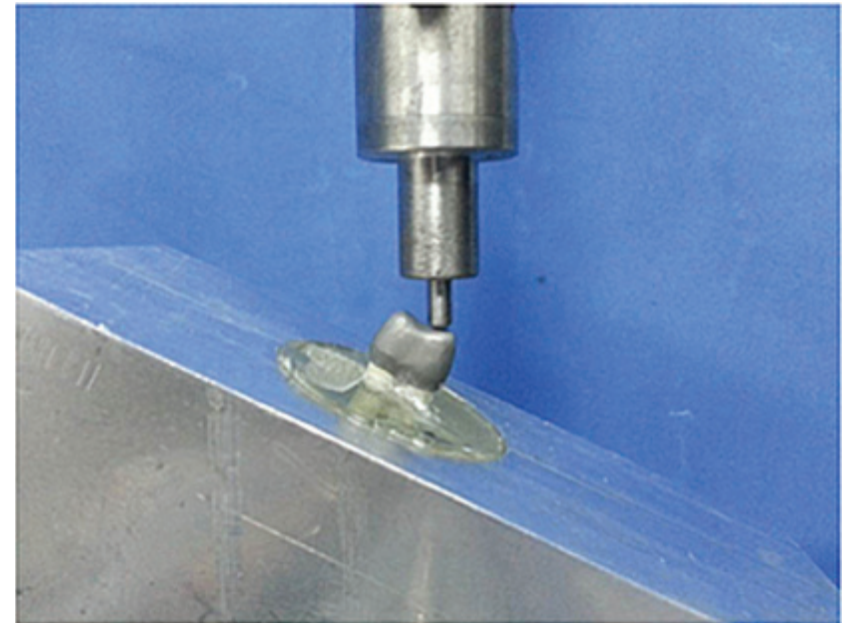

Fig. 1. The position of a specimen in a customized metal holder in a universal testing machine for static loading at $25^{\circ}$

$2 \mathrm{~mm}$ from the central fossa of each crown. The crowns were cemented using self-adhesive resin cement (Multilink Speed ${ }^{\circledR}$; Ivoclar Vivadent).

Each specimen in the resin block was fixed in a customized metal holder in a universal testing machine (Autograph; Shimadzu, Kyoto, Japan), $25^{\circ}$ to the crown (Fig. 1). A compressive load was applied using a stainless steel, round-ended loading rod, $3 \mathrm{~mm}$ in diameter, at a crosshead speed of $0.5 \mathrm{~mm} / \mathrm{min}$. The load was applied on the palatal cusp, $2 \mathrm{~mm}$ from the central fossa. The compressive load was applied until fracture occurred. The data was analyzed using SPSS software, v. 12 (IBM Corp., Armonk, USA). One-way analysis of variance (ANOVA) was employed to compare the mean fracture loads. The significance value was set at $\mathrm{p}=0.05$. The multiple comparisons post hoc Bonferroni test was used to detect significant differences among the groups. The fracture pattern of each specimen was recorded. The fracture mode was classified into either restorable or unrestorable. Fractures occurring as complete or partial post and core debonding, or a post-core-tooth complex fracture above the epoxy resin level were considered restorble. The unrestorable fracture modes were represented by those specimens that displayed a post/core/root fracture below the epoxy resin level, vertical root fractures, or cracks below the epoxy resin level.

\section{Results}

The means of the fracture load and frequencies of fracture modes for all groups are presented in Table 1 . The Shapiro-Wilk test indicated that the dependent variable was normally distributed ( $p>0.05$ ). One-way ANOVA showed that statistically significant differences between the groups $(\mathrm{p}=0.002)$. The post hoc test showed no significant differences between group 3 and group 4 . However, teeth with a post in the palatal canal (group 4) showed 
Table 1. Comparison of fracture loads and failure modes among the groups

\begin{tabular}{|c|c|c|c|c|c|}
\hline \multirow{2}{*}{ Groups } & \multirow{2}{*}{$\begin{array}{l}\text { Fracture load [N] } \\
\quad \text { mean } \pm \mathrm{SD}\end{array}$} & \multirow{2}{*}{$\begin{array}{l}\text { F-statistic* } \\
\text { (df) }\end{array}$} & \multirow{2}{*}{ p-value } & \multicolumn{2}{|c|}{ Failure mode } \\
\hline & & & & restorable $n(\%)$ & unrestorable $\mathrm{n}(\%)$ \\
\hline Control (sound teeth) ${ }^{c}$ & $1215.9 \pm 320.7$ & \multirow{5}{*}{$4(5.13)$} & \multirow{5}{*}{0.002} & $3(30.0)$ & $7(70.0)$ \\
\hline Control (no post) $)^{b, c}$ & $745.46 \pm 265.6$ & & & $8(80.0)$ & $2(20.0)$ \\
\hline Fiber post in buccal canal & $1224.1 \pm 507.4$ & & & $4(40.0)$ & $6(60.0)$ \\
\hline Fiber post in palatal canal ${ }^{\mathrm{a}}$ & $937.2 \pm 128.3$ & & & $6(60.0)$ & $4(40.0)$ \\
\hline Fiber post in both buccal and palatal canals $s^{a, b}$ & $1259.5 \pm 220.1$ & & & $3(30.0)$ & $7(70.0)$ \\
\hline
\end{tabular}

Data is presented as mean \pm standard deviation (SD) or number (percentage). $d f$ - degrees of freedom; * one-way analysis of variance (ANOVA);

aroup 4 vs group $5(p=0.011) ;{ }^{b}$ group 2 vs group $5(p=0.002) ;{ }^{c}$ group 2 vs group $1(p=0.021)$.

lower fracture resistance compared to those restored with posts in both the buccal and palatal canals (group 5) ( $\mathrm{p}=0.011$ ). In addition, group 2 (teeth without a post) had significantly less fracture resistance compared to group 1 (sound teeth) $(\mathrm{p}=0.021)$ and group $5(\mathrm{p}=0.002)$.

As regards failure mode, $40-60 \%$ of the endodontically treated maxillary premolars restored with a fiber post failed catastrophically. According to the results of a series of Fisher's exact tests, different post placement is non-significantly associated with fracture mode $(\mathrm{p}=0.256)$.

\section{Discussion}

The main disadvantage of using human teeth in studies conducted in vitro is the difficulty of specimen standardization due to different physical and mechanical properties of teeth, the morphological variation of the pulp, the aging of the tooth, and the presence of micro-cracks in the dentine. ${ }^{20}$ Therefore, teeth with similar mesiodistal and buccolingual dimensions at CEJ were chosen rather than teeth with a similar crown height. However, standardizing the root morphology and anatomy was an enormous challenge, which might have affected the results of the study. In the tested groups, teeth were decoronated approx. $2 \mathrm{~mm}$ above CEJ to simulate the worst-case scenario with substantial loss of tooth structure, whereby the post must be indicated to retain the core. This was also to provide a 2-millimeter ferrule height, as recommended by other studies. ${ }^{21,22}$ In the present study, teeth were loaded on the palatal cusp, $25^{\circ}$ to the long axis of the tooth, to simulate the presence of non-working side interference. ${ }^{23}$

Many studies have shown that a high percentage of dentists believe that posts do strengthen endodontically treated teeth. ${ }^{24-26}$ The present study demonstrated that teeth restored with fiber posts, resin cement, composite core, and a crown were more resistant to fracture than those without a post. This showed that fiber posts might strengthen severely compromised, endodontically treated premolars. The results of the present study were also in agreement with previous studies, which found that the absence of a post decreased fracture resistance of endodontically treated teeth. ${ }^{27,28}$
However, when a fiber post was placed in the palatal root canals, fracture resistance was not significantly higher compared to the roots without a post. This implied that a post placed in the palatal root canal of maxillary premolars might not provide resistance to fracture when the force was directed on the same cusp (non-working side interference). The current study also demonstrated that a ferrule alone, without a post, could not resist the fracture when the load was applied on the palatal cusp. However, Zicari et al. demonstrated that there was no difference in fracture resistance between the premolars restored with and without fiber posts when a 2-millimeter ferrule was present. This disagreement might be referred to the use of only single-rooted premolars in that study. ${ }^{29}$

In the current study, teeth with a post in the palatal canal showed lower fracture resistance compared to those restored with posts in both the buccal and palatal canals. This can be attributed to the morphology of the buccal root. It was stated that placing the post in the buccal root of bifurcated maxillary premolars must be avoided, as root canal preparation and post preparation resulted in lesser residual dentin thickness. ${ }^{30}$ Since the eccentric force was applied in this study, most of the stress was on the buccal root and with no post placed to support the buccal root, and the residual tooth structure was inadequate to resist the fracture load. However, placing the posts in both the buccal and palatal root canals supports the lesser dentin thickness in the buccal root and enhances fracture resistance.

Even $40-60 \%$ of the endodontically treated maxillary premolars restored with a fiber post in this study failed catastrophically, and the group with a fiber post placed in the palatal canal showed a higher percentage of restorable failure (60\%). This could be attributed to the direction of the force exerted on the palatal cusp, which means that the palatal post is closer to the fracture fulcrum, and thus receives less stress compared to the post placed in the buccal canal. However, normal intraoral masticatory forces are estimated to range between 500 and $600 \mathrm{~N} .^{31}$ Therefore, the results of this study suggest that prefabricated fiber posts can safely be used in maxillary premolars with 2 roots, as fracture resistance proved to be well above $600 \mathrm{~N}$. 
The design of the present study attempted to simulate true clinical situations; however, it is difficult to interpret the results directly for clinical practice. This is due to some limitations, including the fact that it was an in vitro investigation, which could not fully replicate the dynamics of oral conditions. Furthermore, a static load which was applied on 1 point in a monostatic pattern did not represent intraoral conditions. This study evaluated only maxillary first premolars, and thus the results may only be applied to that group of teeth.

\section{Conclusions}

Within the limitations of this study, fiber post location has a significant effect on fracture resistance of severely damaged, endodontically treated maxillary premolars with 2 roots. However, post placement in the palatal root is preferred, as it maintains the restorability of the tooth.

\section{References}

1. Steele A, Johnson BR. In vitro fracture strength of endodontically treated premolars. J Endod. 1999;25(1):6-8.

2. Schwartz RS, Robbins JW. Post placement and restoration of endodontically treated teeth: A literature review. J Endod. 2004;30(5):289-301.

3. Tjan AH, Whang SB. Resistance to root fracture of dowel channels with various thicknesses of buccal dentin walls. J Prosthet Dent. 1985;53(4):496-500.

4. Mohammadi N, Kahnamoii MA, Yeganeh PK, Navimipour EJ. Effect of fiber post and cusp coverage on fracture resistance of endodontically treated maxillary premolars directly restored with composite resin. J Endod. 2009;35(1):1428-1432.

5. Morgano SM, Rodrigues AHC, Sabrosa CE. Restoration of endodontically treated teeth. Dent Clin North Am. 2004;48(2):397-416.

6. Schwartz RS, Fransman R. Adhesive dentistry and endodontics: Materials, clinical strategies, and procedures for restoration of access cavities: A review. J Endod. 2005;31:151-165.

7. Cheung W. A review of the management of endodontically treated teeth. Post, core, and the final restoration. J Am Dent Assoc. 2005;136(5):611-619.

8. Peroz I, Blankenstein F, Lange KP, Naumann M. Restoring endodontically treated teeth with posts and cores: A review. Quintessence Int. 2005;36(9):737-746.

9. Hochman N, Feinzaig I, Zalkind M. Effect of design of pre-fabricated posts and post heads on the retention of various cements and core materials. J Oral Rehabil. 2003;30(7):702-707.

10. Plotino G, Grande NM, Bedini R, Pameijer CH, Somma F. Flexural properties of endodontic posts and human root dentin. Dent Mater. 2007;23(9):1129-1135.

11. Seefeld F, Wenz HJ, Ludwig K, Kern M. Resistance to fracture and structural characteristics of different fiber reinforced post systems. Dent Mater. 2007;23(3):265-271.

12. Makade CS, Meshram GK, Warhadpande M, Patil PG. A comparative evaluation of fracture resistance of endodontically treated teeth restored with different post core systems: An in-vitro study. J Adv Prosthodont. 2011;3(2):90-95.

13. Morgano SM. Restoration of pulpless teeth: Application of traditional principles in present and future contexts. J Prosthet Dent. 1996;75(4):375-380.

14. Mahmoud T, Walton RE. Endodontics: Principles and Practice. $4^{\text {th }}$ ed. St. Louis, MO: Saunders; 2009:322-339.

15. Peutzfeldt A, Sahafi A, Asmussen E. A survey of failed post-retained restorations. Clin Oral Invest. 2008;12(1):37-44.
16. Gutmann JL. The dentine-rot complex: Anatomical and biologic considerations in restoring endodontically treated teeth. J Prosthet Dent. 1992;67(4):458-467.

17. Hargreaves KM, Cohen S. Cohen's Pathways of the Pulp. $10^{\text {th }}$ ed. St. Louis, MO: Mosby Elsevier; 2011:148-233.

18. Rud J, Omnell K-A. Root fractures due to corrosion diagnostic aspects. Scand J Dent Res. 1970;78(5):397-403.

19. Shillingburg HT, Hobo S, Whitsett LD, Jacobi R, Brackett SE. Fundamental of Fixed Prosthodontics. $3^{\text {rd }}$ ed. Chicago, IL: Quintessence Publishing Co., Inc.; 1997:85-103.

20. Fokkinga WA, Kreulen CM, Le Bell-Rönnlöf AM, Lassila LV, Vallittu PK. Creugers NH. In vitro fracture behavior of maxillary premolars with metal crowns and several post-and-core systems. Eur J Oral Sci. 2006;114(3):250-256.

21. Watanabe MU, Anchieta RB, Rocha EP, et al. Influence of crown ferrule heights and dowel material selection on the mechanical behavior of root-filled teeth: A finite element analysis. J Prosthodont. 2012;21(4):304-311.

22. Tan PLB, Aquilino SA, Gratton DG, et al. In vitro fracture resistance of endodontically treated central incisors with varying ferrule heights and configurations. J Prosthet Dent. 2005;93(4):331-336.

23. Dietschi D, Duc O, Krejci I, Sadan A. Biomechanical considerations for the restoration of endodontically treated teeth: A systematic review of the literature - Part 1 . Comparison and micro- and macrostructure alterations. Quintessence Int. 2007;38(9):733-743.

24. Morgano SM, Hashem AF, Fotoohi K, Rose L. A nationwide survey of contemporary philosophies and techniques of restoring endodontically treated teeth. J Prosthet Dent. 1994;72(3):259-267.

25. Eckerbom M, Magnusson T. Restoring endodontically treated teeth: A survey of current opinions among board-certified prosthodontists and general dental practitioners in Sweden. Int J Prosthodont. 2001;14(3):245-249.

26. Naumann, M, Kiessling S, Seemann, R. Treatment concepts for restoration of endodontically treated teeth: A nationwide survey of dentists in Germany. J Prosthet Dent. 2006;96(5):332-338.

27. Salameh Z, Sorrentino R, Papacchini F, et al. Fracture resistance and failure patterns of endodontically treated mandibular molars restored using resin composite with or without translucent glass fiber posts. J Endod. 2006;32(8):752-755.

28. Santana FR, Castro CG, Simamoto-Júnior PC, et al. Influence of post system and remaining coronal tooth tissue on biomechanical behavior of root filled molar teeth. Int Endod J. 2011;44(5):386-394.

29. Zicari F, Van Meerbeek B, Scotti R, Naert I. Effect of ferrule and post placement on fracture resistance of endodontically treated teeth after fatigue loading. J Dent. 2013;41(3):207-215.

30. Pilo R, Shapenco E, Lewinstein I. Residual dentin thickness in bifurcated maxillary first premolars after root canal and post space preparation with parallel-sided drills. J Prosthet Dent. 2008;99(4):267-273.

31. Rosentritt M, Fürer C, Behr M, Lang R, Handel G. Comparison of in vitro fracture strength of metallic and tooth-colored posts and cores. J Oral Rehabil. 2000;27(7):595-601. 
